\title{
What can we Learn from the Ingenius Experiments of prof. Harold Burr almost 100 Years later?
}

\author{
Dr. Maria Kuman* \\ Holistic Research Institute, 1414 Barcelona Dr., Knoxville, TN 37923, USA \\ *Corresponding author: Dr. Maria Kuman, Holistic Research Institute, 1414 Barcelona, Knoxville, USA
}

\begin{tabular}{ll}
\hline ARTICLE INFO & ABSTRACT \\
$\begin{array}{l}\text { Received: } \\
\text { Published: March 15, } 2019\end{array}$ & $\begin{array}{l}\text { Citation: Dr. Maria Kuman. What can we Learn from the Ingenius Experiments of } \\
\text { prof. Harold Burr almost 100 Years later?. Biomed J Sci \& Tech Res 16(2)-2019. BJSTR. } \\
\text { MS.ID.002822. }\end{array}$ \\
\hline
\end{tabular}

\section{Editorial}

There is still what to learn from Prof. Burr's measurements of the electromagnetic field of living beings in the 1930s [1], almost 100 years after. No wonder! The intuitive insights are jumps to the future and they are usually 50 to 100 years ahead of their time [2]. So, it is about time to appreciate his findings. Prof. Burr believed that all life forms not only exhibit electromagnetic properties, but in his words these properties are "the organizing principle" that keeps living tissues from shifting into a chaotic state. Now, we call his "organizing principle" "self-organizing force" and we know that this self-organizing force is electromagnetic in nature and it is nonlinear, which means it does not dissipate. This nonlinear electromagnetic field (NEMF) is very weak (measured in millivolts or milliamperes, which is a millionth part of the volt or ampere). It has informational character and organizes all the cells in the body into one organism. It carries the information for the development of the whole organism and later rules and regulates its functioning [3].

What more can we still learn from Prof. Harold Burr? When measuring the electric characteristics of salamander eggs, Prof. Burr found that even unfertilized egg is electrically polarized - one end has higher electric potential than the other. What he noticed is that after fertilization always from the end with higher electric potential the head of the salamander will develop and from the end with lower electric potential the tail of the salamander will develop. This means that the NEMF is always there - it is present in the unfertilized salamander egg as well. This proves wrong the recent Russian studies [4], which claim that the NEMF enters the ovulated egg at the moment of its fertilization. Prof. Burr's finding that the field is present in the unfertilized egg fully agrees with the statement of the author [5] that everything material comes to this world as a material body and NEMF [6], and this NEMF is a copy of the primary NEMF separating the matter from the antimatter, of which all the matter was created. Thus, each ovulated unfertilized cell has its own NEMF (male or female), but it needs through fertilization to get the NEMF of the opposite sex to become activated and start developing.

As said in [5], the primary androgynous NEMF was split into male NEMF and female NEMF and only when they are joined together the cell gets activated and the development of the embryo could start. Since cancer in its last state malignancy is a "jumbled mass of cells multiplying senselessly" [7], which is a chaotic state, to understand the nature of cancer we must look for changes in the NEMF, which controls the cellular growth. Indeed, in a series of experiments Prof. Harold Burr showed that in the strain of mice specially created to be susceptible to breast cancer, 10 to 14 days before the malignant tumour could be detected with palpitation, he measured increased voltage in their chest area of several thousand microvolts. Thus, the measurements of Prof. Harold Burr proved that measuring NEMF could help us predict oncoming cancer. The next step would be to find a way to restore the normal NEMF between the cells, which control the cellular growth and prevent the cancer. See the article of the author: Physics not Chemistry Will Solve the Cancer Problem [8]. 


\section{References}

1. Burr HS, Hovland CI (1937) Bioelectric Potential Gradients in the Chick Yale Journal of Biology and Medicine 9(3): 247-258.

2. Kuman M (2018) Full Intuitive Creativity Is a Collective Work of the Quantum Computer of Our Subconscious and the Digital Computer of Our Conscious. Journal of Proteomic and Bioinformatics 7(5).

3. Kuman M (2018) The Major Ruling Role of Our Weak NEMF. Journal of Complimentary Medicine and Alternative Healthcare 8(2).

4. Kuman M (2018) Holographic Quantum Ways of Seeing, Hearing, Smelling, Memorizing, and How to Use Them for Diagnosis. Research in Medical and Engineering Sciences 5(3).

\section{ISSN: 2574-1241}

DOI: 10.26717/BJSTR.2019.16.002822

Dr. Maria Kuman. Biomed J Sci \& Tech Res

(c) (i) This work is licensed under Creative

Submission Link: https://biomedres.us/submit-manuscript.php
5. Kuman M (2019) Origin of our NEMF, International Journal of Complementary and Alternative Medicine, 12(4).

6. Kuman M (2019) How was the material world created? Origin if its NEMF, Journal of Mathematics and Theoretical physics, 2 (2)

7. Kuman M (2018) Cancer Is Nonlinear Structural Disorder Caused by Stress. International Journal of Complimentary and Alternative Medicine 11(6): 1791-1797.

8. Kuman M (2018) Physics Not Chemistry Will Solve the Cancer Problem. Research in Medical and Engineering Sciences 6(4).

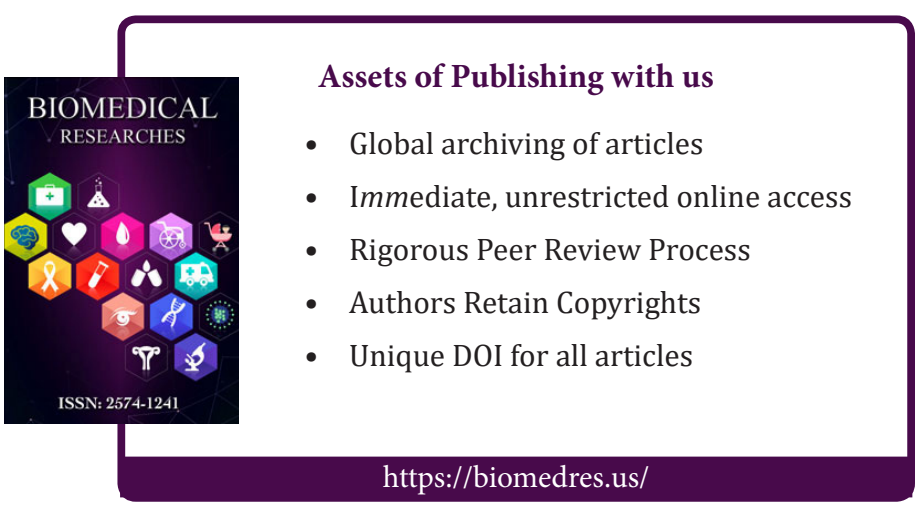

